\title{
ANALYSIS OF DIRECT AND INDIRECT EFFECTS OF FISCAL DECENTRALIZATION ON REGIONAL DISPARITY (CASE STUDY OF PROVINCES IN EASTERN AND WESTERN OF INDONESIA, 2006-2015)
}

\author{
Faishal Fadli \\ Faculty of Economics and Business, Brawijaya University
}

\begin{abstract}
This study aimed to examine the direct and indirect effects of fiscal decentralization on regional disparity through economic growth in eastern and western Indonesia. The method used in this study is Path Analysis. The variables used in this study include the General Allocation Fund (DAU/Dana Alokasi Umum), Special Allocation Fund (DAK/Dana Alokasi Khusus), Revenue Sharing Fund (DBH/Dana Bagi Hasil), local revenue (PAD/Pendapatan Asli Daerah), Economic Growth (G), and regional disparity (IW). Comparing the analysis between eastern and western of Indonesia, the results show that there is no direct effect of fiscal decentralization on regional disparity and economic growth through direct fiscal decentralization on regional disparity in both eastern and western of Indonesia. However, using some measures of fiscal decentralization, in the case of eastern of Indonesia, DAU variable has significant effect whereas in the case of western Indonesia, DBH is the only one variable that has significant effect. This is consistent with the fact that composition of the balance funds disbursed by the central government to local governments, where the greatest composition of funds in eastern Indonesia come from the General Allocation Fund which reflects the dependence of local governments to the central government and for the western region of Indonesia, $\mathrm{DBH}$ is the greatest reflecting the independence of the local governments. As a result, to create fiscal decentralization working it is required a greater allocation of the fund balance.
\end{abstract}

Keywords: Fiscal Decentralization, Economic Growth, Fund Balance, Regional disparity

JEL Classifications: E62, H75

\section{INTRODUCTION}

The aim of the decentralized system of governance is to create an independent local government which is efficient but still under controlled by the central government. So, with the system of self-governance, it is expected that decentralization will accommodate the aspirations of their society as well as be able to explore the local revenue sources efficiently 
Analysis of Direct and Indirect Effects of Fiscal Decentralization on Regional Disparity (Case Study of Provinces in Eastern and Western of Indonesia, 2006-2015)

that will be useful to the national income. To realize this purpose, the central government issued Law No. 22 Year 1999 on Regional Government which has now been converted into Law No. 32 of 2004 and Act No. 25 of 1999 on Fiscal Balance between local government and the central government which has now also been converted into Law No. 33 of 2004.

With the local government's fiscal decentralization, it is expected that each region can explore their potential, where the potential of each region will be used as sources of local revenue. Moreover, with fiscal decentralization, based on Law No. 33 of 2004, it will provide local governments flexibility to increase the local or regional revenue that will be used to finance economic development activities. According to Humes (Muluk, 2006), "the revenue in a decentralized system of government comes from three (3) main sources i.e. local revenue (PAD/Pendapatan Asli Daerah), the transfer of funds from the central government (fund balance) and loans."

Besides, fiscal decentralization is expected to be able to reduce fiscal disparities among regions, providing more efficient public services, and a close relationship with the central government and also society. This is reflected by the allocation of central government funds allocated to the local government, which is expected to boost economic growth and reduce regional disparity.

There are some studies conducted in several countries about the relationship of fiscal decentralization, economic growth and regional disparity. Sakata (2002), Stensel (2005), Zhang and Zou (2001) and Ben (2003) found that fiscal decentralization has a positive effect that can boost economic growth. Similarly, Desai, Freikman and Goldberg (2005) also found that a positive but non-linear relationship between economic growth and tax revenues. Meanwhile Davoodi, and Zhou (1998), Woller and Philip (1998), Jin and Zou (2005 ) determined that fiscal decentralization has a negative effect that could reduce economic growth. In contrast, Rodriguez-Pose and Ezcurra (2010) found that fiscal decentralization can be harmful to the economic growth.

In fact, Indonesia's economy grew at 6.4 percent in the second quarter of 2012, but it was not accompanied by equal distribution of income. Specificaly, regional disparity in Indonesia has become increasingly serious. The Gini Ratio for example increased from 0.33 in 2004 to 0.41 in 2011 showing a greater disparity in the country. If this trend continues then the increase will potentially lead to social fluctuation. The income inequality in 
Analysis of Direct and Indirect Effects of Fiscal Decentralization on Regional Disparity (Case Study of Provinces in Eastern and Western of Indonesia, 2006-2015)

Indonesia is also occurred between western and eastern part of Indonesia, it can be seen by the composition of the fund balance acquired by each province located in eastern and western of Indonesia.

Based on this background, this study examines the direct and indirect effects of fiscal decentralization on regional disparity using the case of provinces in eastern and western of Indonesia. Specifically, the aim of this study is to analyze the effect of direct and indirect equalization funds to regional disparity in both eastern and western provinces of Indonesia.

\section{THEORETICAL AND EMPIRICAL BACKGROUND}

Fiscal Decentralization

In Indonesia, the effort to promotes fiscal decentralization is initially noted by the issuance of Law No. 22 of 1999 on regional government which later revised into Law No. 32 of 2004 to establish the concept of autonomy that has been built since the collapse of new order regime. The law No. 25 of 1999 which deals with fiscal balance between the central government and local governments has also been revised to Act No. 33 of 2004. The term of decentralization itself is not easy to be defined because it covers a very broad institutional. However, in general the decentralization process can be interpreted as a delegation of authority from central government to the lower level of government.

In general, according to Osoro (2003), concept of decentralization consists of political decentralization, administrative decentralization, fiscal decentralization, and economic decentralization. The administrative decentralization is intended to redistribute authority, responsibility and financial resources for providing public services. Administrative decentralization is then can be classified into three types, as follows (i) concentration: delegation of authority from the central government to the officials that in line with the hierarchy of the central government in the region, (ii) devolution to the government at a lower level in finance or administration tasks and the local authorities got uncontrolled direction from the central government, (iii) the delegation of authority for certain tasks to organizations that are outside the regular bureaucratic structure which is not directly controlled by the central government.

According DeMelo (2000), fiscal decentralization is one of the components of decentralization, the fiscal decentralization in the expected future is promote the efficiency 
Analysis of Direct and Indirect Effects of Fiscal Decentralization on Regional Disparity (Case Study of Provinces in Eastern and Western of Indonesia, 2006-2015)

of the public sectors, as well as public accountability and transparency in providing public services and transparent decision-making and democratic. Moreover, according to the World Bank (in Khusaini, 2006), potential gain of fiscal decentralization to regional development is to improve the efficiency of public services, reduce the cost of information, and reduce transaction costs.

Although decentralization is a positive set of idea, it does not mean it will lead to a positive impact, assuming there are three negative impacts of decentralization: first, the importance of national unity and integrity. It is, in particular, for developing countries that are relatively established, where national unity is still fragile so the devolution of power to regions can lead to disintegration. Second, the desire to ensure the provision of a standard similarity of public goods and services, which every citizen has the right the similarity of services/goods, despite of living in an area with has a vary economic capacity and resources. The role of central government in this regard is indispensable in ensuring the provision of similiarity public goods and services among local governments. Third, local governments are less efficient. Often the form of the successful implementation of the local government at the central and regional levels of government is determined by management and the efficient management of local autonomy.

\section{Fiscal Decentralization and Economic Growth}

There are several studies examined related to the relationship between fiscal decentralization and economic growth in Indonesia and abroad. The results of research conducted by Tarin (2003), using panel data of 34 countries during the years 1979 to 1999 showed that fiscal decentralization has a negative effect on the growth of real GDP per capita, but not significantly. Further research also showed that fiscal decentralization creates inefficiency of public services.

Baskaran and Feld (2009) conducted a study to measure fiscal decentralization on economic growth; whether there is a relationship. By using a panel of data, they found that fiscal decentralization is negatively associated with economic growth, but not significantly. Some studies showed that decentralization does not improve revenue growth. Even some evidence that sub-federal oversight over taxes with more economically trigger economic growth. 
Brothaler and Getzner (2010) examined the impact of decentralization on public sector growth in Austria. The purpose of this study was to examine whether fiscal decentralization contribute to the growth of government spending in Austria during the period 1955 to 2007. The results proved that the determinants of the ratio of total government expenditure to GDP can be explained by some explanatory power in the GDP growth rate of the Austrian fiscal policy. Meanwhile, government seems to follow the inverted U-shape that respect for per-capita income, so that at least refuse Wagner's Law, as the first stage in deficit budget financing (public debt increases), so the influence of the business cycle.

Wibowo (2008), analyzed the relationship between fiscal decentralization and local economic growth in Indonesia. By using a panel fixed effect estimation, he found that decentralization in general has a positive impact on regional development during period of 1999-2004. This results strengthen fiscal decentralization theory that fiscal decentralization has the potential contribution in the form of increased government efficiency and economic growth (Oates, 1993).

Hammond and Tosun (2009), examined the local impact of decentralization on economic growth: evidence from US County. The results of this study showed that the the difference impact of fiscal decentralization growth across metropolitan and nonmetropolitan counties. It ia found that the evidence of decentralization can lead to metropolitan growth, especially the growth of manpower and revenue growth (in which single-purpose government fragmentation increases employment growth, while reducing the centralized admission revenue growth). In addition, general-purpose government fragmentation negatively associated with population growth and employment in nonmetropolitan counties. This result is consistent with updated results in the theoretical literature, that fiscal decentralization can be reduce the benefits of demographic diversity in non-metropolitan's countries.

\section{Fiscal Decentralization and Regional disparity}

Bonet (2006) examined the impact of fiscal decentralization on regional disparity in Colombia. By using panel data, it is found that the strong evidence of the process of fiscal 
Analysis of Direct and Indirect Effects of Fiscal Decentralization on Regional Disparity (Case Study of Provinces in Eastern and Western of Indonesia, 2006-2015)

decentralization increases regional disparity. This behavior caused by a set of factors which is currently spending most of resources allocated to a new area (eg, wages and salaries), not capital investment or infrastructure, lack of the component redistribution of national transfers, the lack of adequate incentives ranging from the national level down to the level of area to promote the benefits of their efficient, and lack of institutional capacity in local government.

The empirical analysis of the results also proved that the essential elements of fiscal decentralization policy can affect regional disparity across regions namely equitable transfer system, the ability to select the sector, where resources are allocated, and the application of the correct incentives. These elements have an important role in the success of decentralization to reduce regional income disparities. According to Bonet (2006), there are two variables that need to be controlled; degree of economic openness and economic agglomeration tendencies, which is have a negative impact on regional disparity."

Rodriguez-Pose and Ezcurra (2010) analyzed the relationship between decentralization and regional disparity in developed countries and developing country. The results proved that the developed countries do not affect the evolution of political decentralization inequality between regions, while fiscal decentralization contributes to reduce the regional disparities. In contrast, in the developing countries fiscal decentralization has sparked a significant rise in regional disparity. The increasing of inequality cannot be compensated by the positive effects of political decentralization of the political interregional disparities in this country. Most of these countries have less of the capacity of redistribution in rich countries, so the decentralization has the potential impact on increasing inequality between regions.

Widhiyanto (2008) examined the fiscal decentralization and regional disparity in Indonesia during the years 1994 to 2006. Consider of economic convergence, of empirical evidence during the period 1994-2000 there were economic divergence, while, in the period 2001-2004 there is an economic convergence. This finding is consistent with new theory of fiscal decentralization. Sigma convergence did not occured because the coefficient of variation of per capita income fluctuates during the observation period. Meanwhile, the implementation of the policy of fiscal decentralization of the local governments face coefficient of higher revenue of variation of per capita because the area has many natural 
resources that can give them a benefit, areas which are lack of natural resources does not have an advantage. Another finding showed that fiscal decentralization has a negative impact to the regional per capita income disparities.

Lessman (2006) examined the impact of fiscal decentralization on regional disparity. The finding indicate that countries with a high levels of decentralization has relatively small inequality. It means that the distribution between regions in decentralization is not harmful, but quite vice versa, decentralization reduce regional disparity. These results can only be generalized to highly developed countries. While, decentralization in poor countries has a negative impact on regional equity.

Akai and Sakata (2005) examined the fiscal decentralization, commitment and regional disparity. By using cross-sectional data of the United States, including regional income convergence suggests that, there is a relationship between fiscal decentralization to regional disparity. The direction of the relationship, depends on how the fiscal decentralization promoted. While the impact of the distribution is directly dependent on the share of the central government, as well as the impact of incentives depending on the level of autonomy. The results showed that local expenditures or revenue share on fiscal decentralization has no significant effect on regional disparity, while achieving autonomy by fiscal decentralization has a negative effect on regional disparity.

\section{Research Framework}

Based on the grand theory proposed by Simon Kuznets that high economic growth will slowly but surely bring to the conical regional disparity. That can be ascertained from several previous studies above that fiscal decentralization can promote economic growth that creates regional disparity, it can be said to be successful or not by looking at the results of this study. Therefore, to compare the developed and developing areas can be divided into two areas. In example; East Indonesia area as representations of developing area in Indonesia and west as representations of developed areas in the provinces in Indonesia.

In this regard it is interesting to do the assessment and verification whether the implementation of fiscal decentralization can be improved economic growth and regional disparity or make it in the other way around. An interim response, the authors argue that fiscal decentralization can promote economic growth and reduce the regional disparity. 


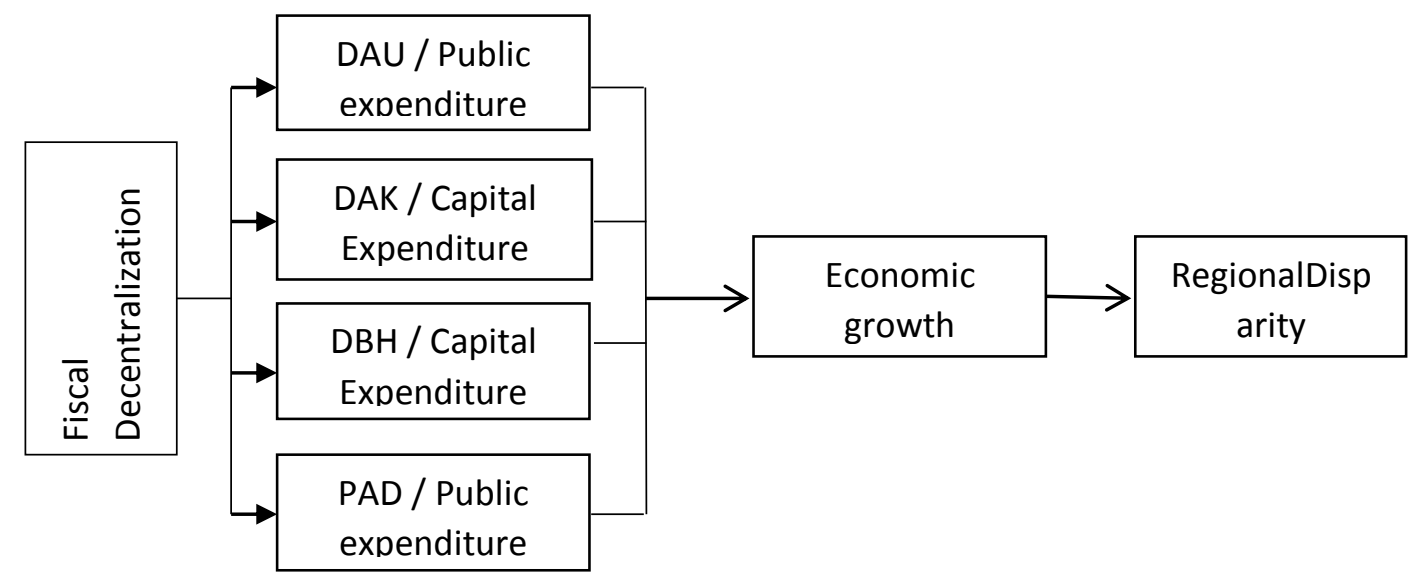

\section{Figure 1. Fiscal Decentralization relation to Regional Disparities Through Economic Growth}

Based on the conceptual framework and explanations above, the hypothesis in this paper is based on theoretical literature and empirical literature on fiscal decentralization, economic growth and regional inequalities as follows:

H1: It is predicted that fund balance has a positive effect on economic growth.

H2: It is predicted that funds off setting has a negative effect on regional disparity.

H3: It is predicted that economic growth has a negative effect on regional disparity.

\section{Research Methods}

The reserch approach which is used in this study is a positivist approach. According to Neuman (2006). The positivist approach is an organized method for combining deductive logic with precise empirical observations of the behavior of individuals or groups to discover and confirm a set of causal laws that can be used to predict general patterns of human activities. The positivist approach, in addition is to analyze the direct and indirect relationships between variables and the balance fund revenue as a proxy of fiscal decentralization on regional disparity through economic growth.

\section{Definition and Measurement of Variables}

The definition and measurement of variables is intended to explain the variable being studied. In other words, the variable definitions are guidelines how to measure a variable in this study. 
Analysis of Direct and Indirect Effects of Fiscal Decentralization on Regional Disparity (Case Study of Provinces in Eastern and Western of Indonesia, 2006-2015)

\begin{tabular}{|c|c|c|}
\hline No & Variable & Measurement of Variables \\
\hline 1 & $\begin{array}{l}\text { Fiscal } \\
\text { Decentralization }\end{array}$ & $\begin{array}{l}\text { Ratio Balance Funds (DAU, DBH, DAK, and PAD) } \\
\text { District to the total expenses per year. }\end{array}$ \\
\hline 2 & Economic growth & $\begin{array}{l}\text { Logarithmic Natural (ln) Gross Domestic Regional } \\
\text { Product (PDRB) per capita of all the Province in } \\
\text { Indonesia. }\end{array}$ \\
\hline 3 & Regional disparity & $\begin{array}{l}\text { Constant price GDP inequality between districts / } \\
\text { municipalities in the province by the method of } \\
\text { Williamson Index. }\end{array}$ \\
\hline
\end{tabular}

\section{Data Analysis}

The aim of the data analysis is to test the hypothesis of the research problems. Therefore, the collected data sources have the time series and cross-section, the data analysis methods used by is a panel data analysis methods. By accommodating variable-variable cross-section and time series, panel data is able to reduce omitted-variables because these models ignore the relevant variables addition, it can overcome the inter-correlations among the independent variables that can lead to an inaccurate assessment of regression (Nachrowi and Usman, 2006).

As an answer to the formulation of the problem it has been mentioned previously, that this study will use the method of path analysis (path analysis). The reason is due to the path variable used is the recursive path as known as one-way influence. Relationships between variables and the balance fund revenue is direct relationship with economic growth variable. Similarly, the relationship of economic growth with economic inequality is olny a direct relationship, because if the relationship is reciprocal relation or two-way path analysis methods used are not biased. 


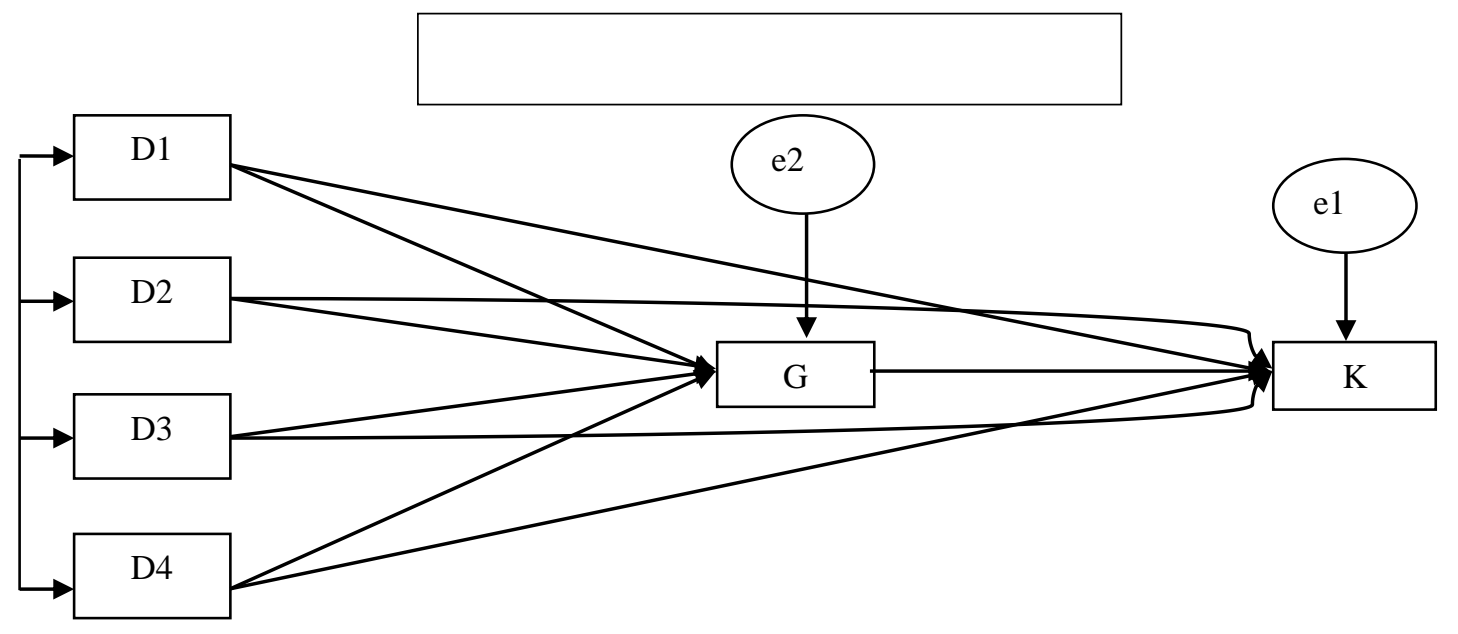

Figure 2

\section{Hypothetical model of Operational}

\section{EMPIRICAL RESULTS}

\section{Testing Analysis Model}

As explained earlier, this study uses the panel data, which are the combination of the data time series and cross-sectional, while the modeling approach using path analysis or path analysis. From table 2, it can be seen that there is a direct effect of the equalization fund (DAU) and revenue (PAD) on regional disparity (IW) without going through economic growth (G) and the indirect effect of the equalization fund (DAU) and Revenue (PAD) on regional disparity (IW) through economic growth (G). It can be shown on the p-value of direct and indirect influence of grants (DAU) and revenue (PAD) on regional disparity (K) which are under the $5 \%$ level.

When viewed from the $t$ value that can be seen from the value of $C R$, the overall effect of direct and indirect grants (DAU) and revenue (PAD) on regional disparity (IW) is greater than $t$ table $(>1.658)$ and showed a negative relationship. This indicates that the Fund Balance significantly affects the regional disparity. Negative influence indicates that an increase in the equalization fund (DAU) and revenue (PAD) will be able to reduce regional disparity (IW). The state in accordance with the theory and purpose of the fund balance itself which is to reduce regional disparities between provinces in both Western and Eastern Indonesia. 
Analysis of Direct and Indirect Effects of Fiscal Decentralization on Regional Disparity (Case Study of Provinces in Eastern and Western of Indonesia, 2006-2015)

Table 2. Eastern Indonesia Region Testing Results

\begin{tabular}{|c|c|c|c|c|c|}
\hline Variables & CR & $\begin{array}{l}\text { Standardized Indirect } \\
\text { Effect }\end{array}$ & $\begin{array}{l}\text { Standardized } \\
\text { Direct Effect }\end{array}$ & t table ${ }^{* *}$ & Decision \\
\hline$G<-\quad D A K$ & .199 & .019 & .008 & 1.658 & $\mathrm{H}_{0}$ accepted \\
\hline$G<-\quad D B H$ & 1.331 & .118 & .267 & 1.658 & $\mathrm{H}_{0}$ accepted \\
\hline$G<-D A U$ & 3.022 & .301 & .268 & 1.658 & $\mathrm{H}_{0}$ rejected \\
\hline$G<-\quad P A D$ & 4.712 & .422 & .968 & 1.658 & $\mathrm{H}_{0}$ rejected \\
\hline IW <- DAU & 1.680 & -.144 & -.021 & 1.658 & $\mathrm{H}_{0}$ rejected \\
\hline IW <- PAD & 4.066 & .329 & .122 & 1.658 & $\mathrm{H}_{0}$ rejected \\
\hline IW $<-\quad G$ & 6.078 & .476 & .077 & 1.658 & $\mathrm{H}_{0}$ rejected \\
\hline IW <- DAK & 1.296 & -.101 & -.007 & 1.658 & $\mathrm{H}_{0}$ accepted \\
\hline $\mathrm{IW}<-\mathrm{DBH}$ & 1.250 & -.092 & -.034 & 1.658 & $\mathrm{H}_{0}$ accepted \\
\hline
\end{tabular}

Note: * significant at the $5 \%$ level, ${ }^{* *}$ t table value for $\mathrm{df} 120$ and a significance level of $5 \%$ (one-sided)

If the view of economic growth (G), in the above table shows the value of CR and the p-value is negative and significant. This means that the increase in economic growth $(G)$ resulted in increased regional disparity (IW). This is possible because according to the theory advanced by Simon Kuznets that the developing countries are still in line with the economic growth it will be followed by the development of regional disparity. It can be said that the test in accordance with the existing theory.

It can be seen the influence of grants (DAU) on economic growth (G), in the above table can be seen that the value of CR indicates a positive value. So the increasing in grants (DAU) fund raise economic growth $(G)$ although the p-value showed no significant within $5 \%$ significance level.

The dominant factor affected regional disparity (IW) is the equalization fund (DBH), it can be seen from a standardized coefficient and direct effect on a standardized regression 
Analysis of Direct and Indirect Effects of Fiscal Decentralization on Regional Disparity (Case Study of Provinces in Eastern and Western of Indonesia, 2006-2015)

weight (attachment) which is indicated by the value of the largest coefficient. Path analysis in the form of the equation for the line:

1. Substructure I the influence of grants (DAK, DAU, DBH) and PAD on economic growth $(\mathrm{G})$ is as follows: $\mathrm{G}=0.199 \mathrm{D} 1+\mathrm{D} 2+1,331+4,712$ 3,022 D3 D4 + e1

2. Substructure II the influence of grants (DAK, DAU, DBH) and PAD to regional disparity (IW) is as follows: IW $=-1680+\mathrm{D} 1+\mathrm{D} 2$ 4,066 6,078 D3 - D4 1,296 - 1,250 G + e2

From the table below, it can be seen that there is no direct effect of grants (DBH) of the regional disparity (IW) through economic growth (G) and the direct effect of grants (DBH) and revenue (PAD) on regional disparity (IW). It can be shown on the p-value is not directly influence grants (DBH) and revenue (PAD) of the income of inequality (K) through economic growth $(G)$ and the direct effect of grants (DAK, DAU, DBH) revenue (PAD) on regional disparity (IW) which are in the $5 \%$ level, while the p-value is not directly influence grants (DAK, DAU) on economic growth (G) above the significance level of $5 \%$.

Looking at the $t$ value, it that can be seen from the CR that there is a positive effect of grants (DBH) and revenue (PAD) on economic growth $(\mathrm{G})$, the negative effect of revenue (PAD) on regional disparity $(\mathrm{K})$, and the negative impact of economic growth (G) against regional disparity (IW) is greater than $t$ table $(>1,96)$. The positive impact of grants (DAU) on economic growth $(G)$ shows that any increase in grants (DAU) will result in an increase in economic growth. Negative influence of local revenue (PAD) on regional disparity (IW) has the meaning that the greater revenue and local revenue (PAD) will impact the decline in regional disparity (IW). As for the positive impact of economic growth (G) against regional disparity (IW) has the meaning that the higher the economic growth (G) then it will have an increasing impact of regional disparity (IW). Then it can be decided from the results of the hypothesis that: Fund balance (DBH) has positive effect on economic growth (G) and fund balance (DBH) negatively affects regional disparity (IW) through variable economic growth (G). It could be happen, when the fund balance (DBH) plus it will have an impact on economic growth $(G)$ is increased. Simon Kuznets theory based on the rapidly growing economy will lead to higher inequality also to a certain extent. 
Analysis of Direct and Indirect Effects of Fiscal Decentralization on Regional Disparity (Case Study of Provinces in Eastern and Western of Indonesia, 2006-2015)

Table 4. Western Indonesia Region Testing Results

\begin{tabular}{|c|c|c|c|c|c|}
\hline Variables & CR & Standardized Indirect Effect & Standardized Direct Effect & t table *** $^{2}$ & Decision \\
\hline$G<-D A K$ & -.240 & -.024 & -.013 & 1.658 & $\mathrm{H}_{0}$ accepted \\
\hline$G<-D B H$ & 2.042 & .188 & .023 & 1.658 & $\mathrm{H}_{0}$ rejected \\
\hline$G<-D A U$ & -1.757 & -.169 & -.286 & 1.658 & $\mathrm{H}_{0}$ accepted \\
\hline$G<-P A D$ & 1.902 & .180 & .235 & 1.658 & $\mathrm{H}_{0}$ rejected \\
\hline $\mathrm{K}<-\mathrm{DAU}$ & -.011 & -.015 & -.707 & 1.658 & $\mathrm{H}_{0}$ accepted \\
\hline $\mathrm{K}<-\quad \mathrm{PAD}$ & 3.779 & .213 & .075 & 1.658 & $\mathrm{H}_{0}$ rejected \\
\hline$K<-G$ & 15.477 & .822 & .172 & 1.658 & $\mathrm{H}_{0}$ rejected \\
\hline $\mathrm{K}<-\mathrm{DAK}$ & -.833 & -.048 & -.006 & 1.658 & $\mathrm{H}_{0}$ accepted \\
\hline $\mathrm{K}<-\mathrm{DBH}$ & -.462 & -.025 & -.001 & 1.658 & $\mathrm{H}_{0}$ accepted \\
\hline
\end{tabular}

Note: ${ }^{*}$ significant at the $5 \%$ level, ${ }^{* *} \mathrm{t}$ table value for $\mathrm{df} 120$ and a significance level of $5 \%$ (onesided)

The dominant factor affected regional disparity (IW) is the equalization fund (DBH), it can be seen from a standardized coefficient and direct effect on a standardized regression weight (attachment) which is indicated by the value of the largest coefficient. Path analysis in the form of the equation for the line:

1. Substructure I the influence of grants (DAK, DAU, and DBH) and PAD on economic growth (G) is as follows: $G=-0240 D 1+D 22,042-1,757$ 1,902 + D3 + D4 e1

2. Substructure II the influence of grants (DAK, DAU, and DBH) and PAD to regional disparity (IW) is as follows: IW = -0011 D1 + D2 + 154773779 D3 - D4 0833 - 0462 $\mathrm{G}+\mathrm{e} 2$ 
Analysis of Direct and Indirect Effects of Fiscal Decentralization on Regional Disparity (Case Study of Provinces in Eastern and Western of Indonesia, 2006-2015)

\section{Impact of Fiscal Decentralization on Regional Economic Growth}

Fiscal decentralization policy as a drive the economic development of the region has become a concern by many experts. From the basic point of view fiscal decentralization is the delegation of authority and responsibility from central government to local governments to manage financial resources because the area is expected to create efficiency and effectiveness of local economic activity as per your preferences and needs of local communities. Fulfillment of the needs of the local community by itself will encourage regional economic growth which is can improve the welfare of the people [(Oates1993, 2007; Bird, 2000; Khusaini, 2006; Bahl, 2008; Yustika, 2008; and Ananda, 2010)].

Problem of limited funds to financial development activities increased fiscal imbalances between regions. Implementation of the fiscal decentralization policy is one of the instruments in order to reduce the fiscal imbalance. The results proved that to reduce the impact caused by the existence of the fiscal imbalance, over the last ten years ie from the year 2006-2015, the funds allocated by the central government to local governments continued to increase, on average per year is 20.86 percent or by Rp.9.84 trillion.

An increasing number of decentralized funds that continue to show the improvement, should also be accompanied by a better service to the community. But the reality is far from the expectations. The results showed that the allocation of funds transfer contribution to economic growth only for fiscal decentralization coefficient reached 3.68 percent, equivalent to 0.36 percent ( 362.1 billion per year) of the average fund balance (DP) allocated in budget. With the decentralization of funds every regions or area of the province of East and West Indonesia only gained 0.06 percent or 22.6 billion dollars per year to fund local economic development activities. Means that only a small percentage allocation of budget funds to finance the construction absorbed the real sector, while the remaining 96.32 per cent for non-real sector spending. 
Analysis of Direct and Indirect Effects of Fiscal Decentralization on Regional Disparity (Case Study of Provinces in Eastern and Western of Indonesia, 2006-2015)

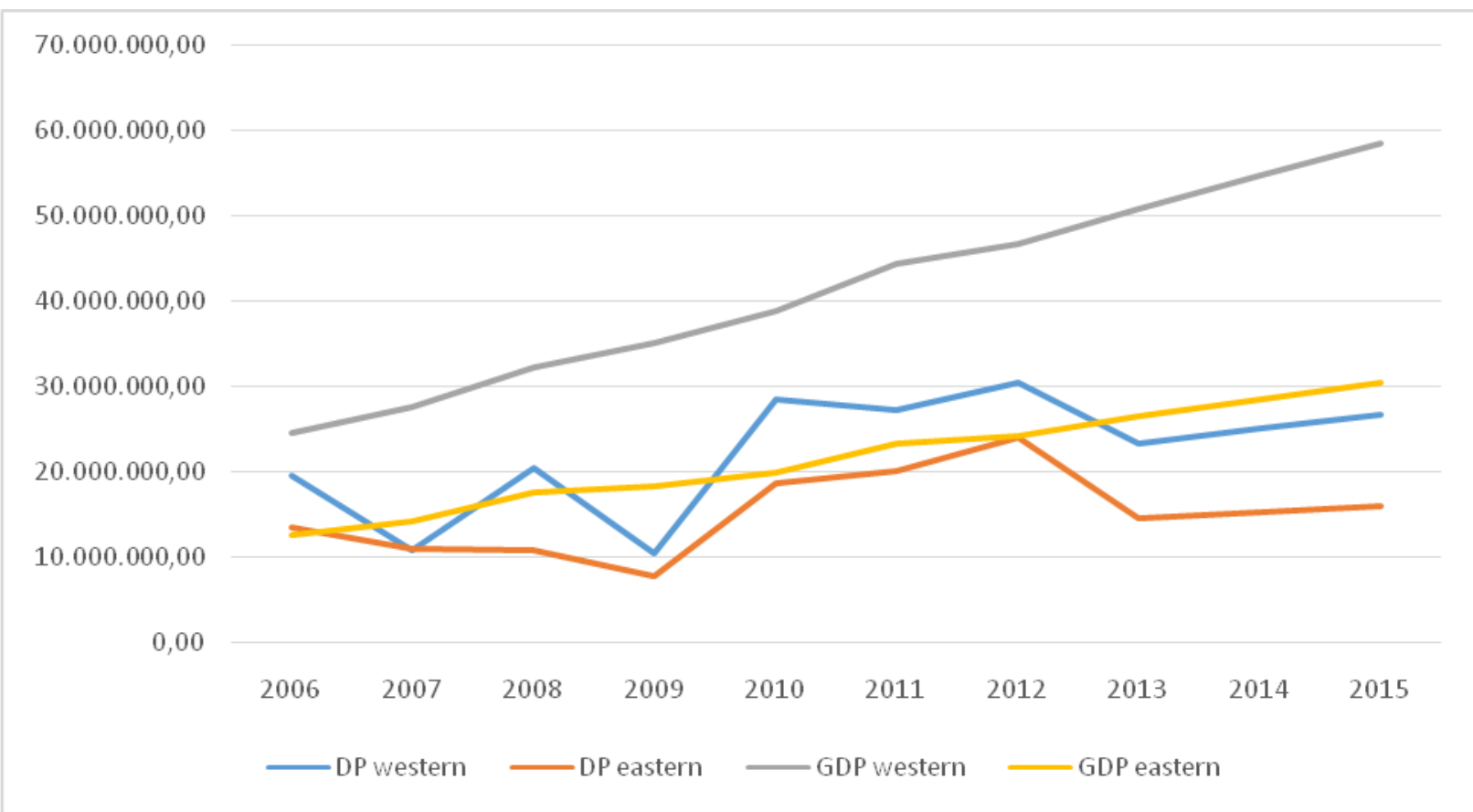

Source: Calculated from BPS, 2015

\section{Figure 3. Average Fund Fiscal Decentralization and GDP Per Capita In Eastern and Western Indonesia, 2006-2015}

Local governments are required to be careful in defining and implementing development policies in the region without having to override one of the factors, so it does not have a negative impact on the sustainability of regional development in the long term. This is the main core of the Decentralization Theorem as mentioned by Oates (1972 and 2007). According to Oates (1972 and 2007), any consumption of the public good is defined as a set of geographically part of the total population, and every sacrifice yield benefits in every jurisdiction similar to the central government or any local government and will always try to be more efficient (or at least efficient) so that it can achieve a Pareto-efficient level of output in any jurisdiction which in turn will impact on all aspects evenly.

This means that fiscal decentralization have a positive impact because it creates a level of efficiency in many areas of development, especially related to the provision of better services to the public. With the provision of better services, other development activities were also affected, to grow and evolve, so will indirectly encourage local economic growth which in turn is expected to improve the welfare of the community. 
Analysis of Direct and Indirect Effects of Fiscal Decentralization on Regional Disparity (Case Study of Provinces in Eastern and Western of Indonesia, 2006-2015)

Thus, the results of this study have proved that fiscal decentralization is positively and significantly to regional economic growth in Eastern and Western Indonesia. These finding as well as a strengthening the theory and previous empirical studies on the effects of fiscal decentralization on economic growth, among others; Oates (1993, 2007), Akai and Sakata (2002), Khusaini (2006), Jin and Zou (2003), and Wibowo (2008). Their point of view is the core of fiscal decentralization has the potential to improve efficiency at the level of government and promote economic growth.

\section{Impact of Fiscal Decentralization on Regional disparity}

Fiscal decentralization is expected to have a positive impact on regional economic growth based equitable income distribution and optimization of local government expenditure, but its realization depends on the level of readiness of each fiscal area. Inability of the region to efficiently allocate funds that are not supported by good administrative system and the low power of redistribution of resources between regions (counties / cities) in one province will inhibit the growth and economic development of the region and increase regional disparity.

As explained earlier that fiscal decentralization is expected to have a positive impact on regional economic growth based equitable income distribution and optimization of local government expenditure. It means the necessary fiscal readiness of each region. Therefore, the ability of the region to allocate funds efficiently and effectively must be supported by a system of administration and strength of regional redistribution of resources, if not could hamper economic growth and development which could eventually boost regional disparity.

The relationship between fiscal decentralization and the current imbalance is a concern by most economists. Akai and Sakata (2005) in their study found that the direction of the relationship of fiscal decentralization and regional disparity depends on how fiscal decentralization in promoted. There are two directions: (1) relate to the distribution or allocation of the budget, (2) the degree of autonomy. According to Akai and Sakata (2005) that local expenditures in fiscal decentralization does not have a significant effect on regional disparity, while achieving autonomy in fiscal decentralization has a negative effect 
Analysis of Direct and Indirect Effects of Fiscal Decentralization on Regional Disparity (Case Study of Provinces in Eastern and Western of Indonesia, 2006-2015)

on regional disparity. The findings Akai and Sakata (2005) implicitly have in common with the findings of researchers, namely the allocation of budget expenditures is not on target, and administrative systems and devices become the key of institutional decentralization degree attainment.

Moreover, this result is also consistent with the view of Bonet (2006), that the behavior that caused the decentralization relationships with regional disparity is caused by several factors, namely the current spending most of the resources allocated to a new area (eg , wages and salaries) , not used for capital investment or infrastructure ; lack of national transfer redistribution component; absence of adequate incentives ranging from the national to the local level to promote the benefits of efficiency, and lack of institutional capacity. Therefore, according to Bonet (2006) that the essential elements that need attention in the implementation of fiscal decentralization that could affect regional disparity is a fair transfer system, the ability to select the sector to allocated resources and the application of the correct incentives. Meanwhile, the elements that need to be done is related to the level of supervision of economic openness and economic agglomeration tendency because it could lead to regional disparity.

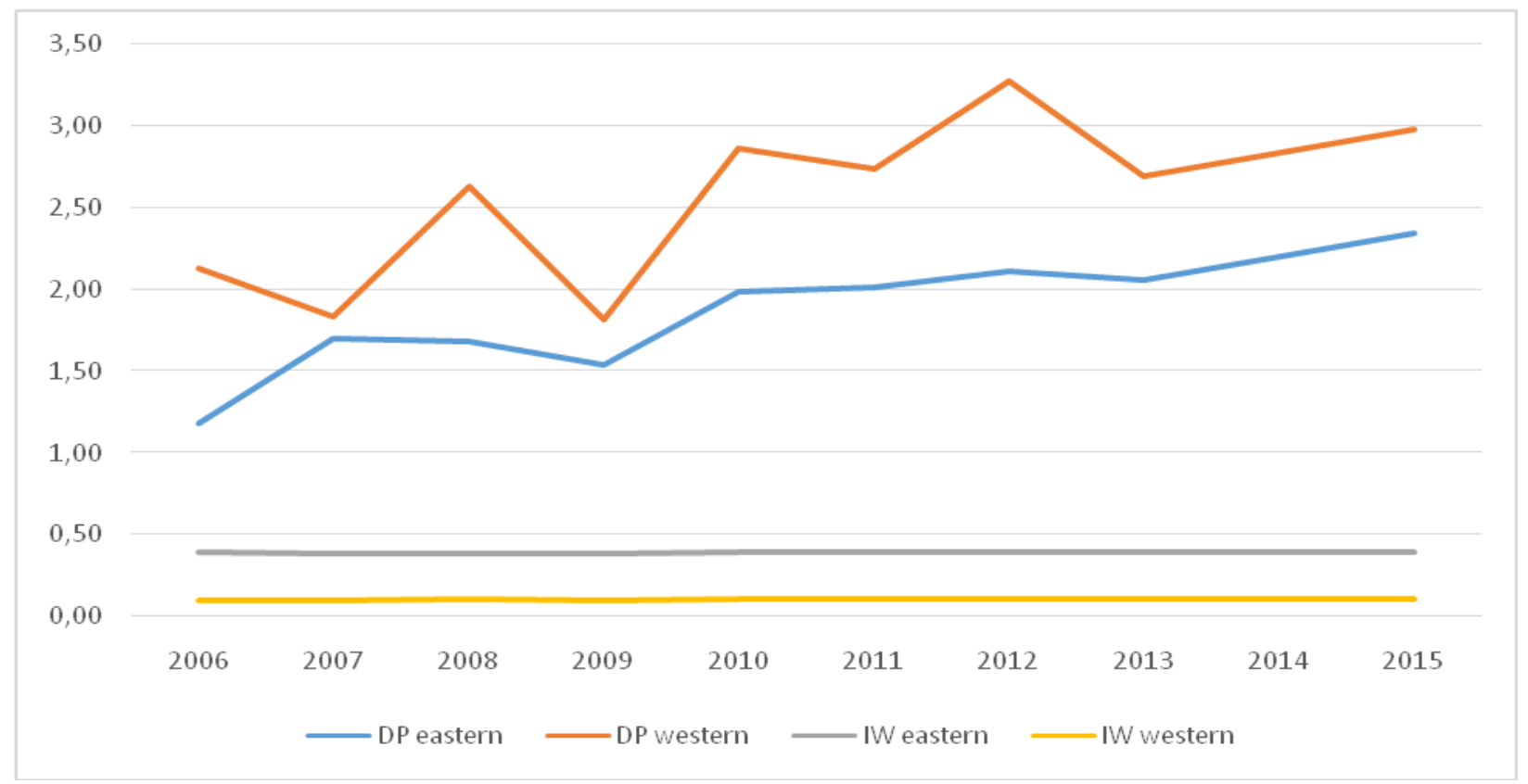

Source: Calculated from BPS, 2012

Figure 4. Relationships between Fiscal Decentralization and Regional Disparity 
Thus, these findings, as well as support for the results of previous researchers, showed that fiscal decentralization has a negative relationship to regional disparity, but also in response to the majority of previous researchers who said that fiscal decentralization has a positive relationship and even dangerous effect because it will make the local economy getting worse, particularly for developing countries (Rodriquez-Pose and Ezcurra, 2010) which is cannot be accounted.

\section{CONCLUSION}

Fiscal decentralization has a positive impact on regional economic growth. It means that the balance funds have a proven the ability to drive regional economic growth in both Eastern and Western of Indonesia. Meanwhile, the relationship of fiscal decentralization with regional disparity confirms that fiscal decentralization has the ability to reduce regional disparities in both Eastern and Western of Indonesia.

The results indicate that in Eastern of Indonesian, General Allocation Fund and the Special Allocation Fund's are the most influential factors to grow the economy and to create regional disparity. Moreover, in Eastern of Indonesia it is dominated by DBH. This shows that the regions in Eastern of Indonesia mostly they still rely on the central government than regions in Western of Indonesia. In general, the results of this study confirm that although the fund balance as a fiscal decentralization policy instruments continued to increase every year, but the views of the proportions tend to fall. A decrease in the decentralized allocation due to lack of funding in addition to the government, but also as a result of the emergence of the expansion areas. Most of the expansion areas are classified

into regions with economic growth and per capita income is low, so that it needs a necessary role of government intervention and a more evenly balanced in the allocation of funds and decentralization. 
Analysis of Direct and Indirect Effects of Fiscal Decentralization on Regional Disparity (Case Study of Provinces in Eastern and Western of Indonesia, 2006-2015)

\section{REFERENCES}

Abimanyu A, Megantara A 2009, Era Baru KebijakanFiskal :Pemikiran, KonsepdanImplementasi. Jakarta :Kompas

Akai, Nobuo. dan Sakata, M., 2002. Fiscal Decentralization Contributes to Economic Growth: Evidence from State-Level Cross-Section for the United States, Journal of Urban Economics, LI1:93-108

Akai, Nobuo. dan Sakata, M., 2005. Fiscal Decentralization Commitment and Regional disparity Evidence from State-Level Cross Section Data for the U.S., Faculty of Economic University of Tokyo.

Akai, Nobou., Masayo Hosoi and Yukihiro Nishimura. 2009. Fiscal Decentralization and Economic Volatility: Evidence From State-Level Cross-Section Data of the USA. The Journal Economic Review, Vol. 60, No. 2

Ananda, CandraFajri. 2010. RestorasiKebijakanDesentralisasiFiskal di Indonesia (PengalamanJawaTimur), PidatoPengukuhanJabatan Guru BesardalamBidangIlmuEkonomiKeuanganPadaFakultasEkonomiUniversitasBrawija ya Malang, Tanggal 30 Desember 2010.

Bahl, Roy. 1999. Implementation Rules For Fiscal Decentralization. Working Paper, Georgia State University

Barro, Robert J, 1994. Democracy and Growth, National Bereau of Economic. Research (NBER), Working Paper No.4909, October 1994.

Bird, R.M. 1993. Threading The Fiscal Labyrinth : Some Issues Fiscal Decentralization, National Tax Journal, 46 (3) : 207-227

Boadway R, Hobson 2007. Intergovernmental Fiscal Transfer : Principle and Practice. Washington DC. World Bank

Bonet, Jaime. 2006. Fiscal Decentralization and Regional Income Disparities : Evidence from The Colombian Experience. Original Paper.

Canaleta, C. Gil, Pedro Pascual A and Manuel R. G. 2004. Regional Economic Disparities and Decentralization. Urban Studies, Vol. 41, No. 1, 71-94

Clark, Todd E, 1995. Rents and prices of housing across areas of the United States. Regional Science \& Urban Economics, Volume. 25 Issue 2, pp. 211-237

Davoodi, H. and H. Zou, 1998. Fiscal Decentralization and Economics Growth: A Cross Country Study. Journal of Urban Economics 43. Page 224-257

Devkota. K L. 2010. Impact of Fiscal Decentralization on Economic Growth of Nepal.

Dana perimbangandanbelanjadaerah data series. www.djpk.go.iddiaksespadatanggal 15 November 2012

Ghozali, Imam. 2011. KonsepdanAplikasiDengan Program AMOS 19.0. Semarang

Gujarati, D.1999. Essential of Econometrics, McGraw-Hill.Inc. Second Edition, London. 
Analysis of Direct and Indirect Effects of Fiscal Decentralization on Regional Disparity (Case Study of Provinces in Eastern and Western of Indonesia, 2006-2015)

Hall, David, 2010. Mengapakitamembutuhkanbelanjapublik. University of Greenwichwww.psiru.org.

Jin, Jing and Hong-fu Zou, 2003. Fiscal Decentralization and Economic Growht in China, Development Research Group, World Bank.

Khusaini, Mohammad. 2006. EkonomiPublikDesentralisaiFiskaldan Pembangunan Daerah. BPFE UniversitasBrawijaya. Malang

Kuncoro, M. 2004. Otonomi Daerah: Reformasi, Perencanaan, StrategidanPeluang. Jakarta: Penerbit Erlangga.

Lessmann C. 2006. Fiscal decentralization and regional disparity.: a panel data approach OECD countries. Working Paper. Ifo Institute for Economic Reseach, Germany.

Meta data indonesia data series. www.data.worldbank.orgdikasespadatanggal 15 November 2012

Musgrave, Richard A and Peggy B. Musgrave, 1989, Public Finance in Theory and Practice, Mc Graw-Hill

Oates, Wallace E., 1972. Fiscal Federalism, Harcourt Brace Jovanovich. New York

Oates, Wallace E., 1993. Fiscal Decentralization and Economic Development. National Tax Journal, LXVI (2): 237-34

Oates, Wallace E., 1999. An Essy on Fiscal Federalism, Journal of Economic Literature, Vol. 37. No. 3. Pp, 1120 - 1149

Oates, Wallace E. 2007. On The Theory And Practice Of Fiscal Decentralization. Centro di RicercaInterdipartimentale di EconomiadelleIstituzioni (CRIEI) Working Paper No. 1/2007PDB data series. www.bps.go,iddikasespadatanggal 15 November 2012

PMA dan PMDN data series. www.bkpm,go,iddikasespadatanggal 15 November 2012

Persson, TorstendanGoidoTabellini. 2003. The Economic Effect of Constitution, The MIT Press Cambridge, Massachusetts London, England

Republik Indonesia. 1999. Undang-UndangNomor 22 Tahun 1999 tentangPemerintah Daerah

Republik Indonesia. 2000. Undang-UndangNomor 34 Tahun 2000 tentang Pajak danRetribusi Daerah

Republik Indonesia. 2004. Undang-UndangNomor 33 Tahun 2004 tentangPerimbanganKeuangan Antara Pemerintah Pusat dan Daerah

Rodriguez A, Ezcurra R 2009. Does Decentralization Matter for Regional Disparities? ESRC, Department for Business, Enterprise and Regulatory Reform

Rodriguez and Kroijer R 2009. Fiscal Decentralization and economic growth in central daneastern Europe. LSE' Europe in Question' Discussion Paper Series. The London School of Economic and Political Science

Sarundajang. 2002. ArusBalikKekuasaan Pusat ke Daerah. PustakaSinarHarapan. Jakarta 
Analysis of Direct and Indirect Effects of Fiscal Decentralization on Regional Disparity (Case Study of Provinces in Eastern and Western of Indonesia, 2006-2015)

Tiebout, Charles M, 1956. Pure Theory of Local Expenditure, The Journal of the Political Economic. Volumme 54, Issue 5 (Oct., 1956), 416 -424

Todaro, Michael, P. 2000. Pembangunan Ekonomi dan Pemerataan Pendapatan. LP3ES, Jakarta.

Williamson JG. 1965. Regional disparity and the process of national development: A description of the patterns. Economic Development and Cultural Change. 13(4):158-200

World Bank, 2005. East Asia Decentralizes: Making Local Government Work, Washington DC 20433.

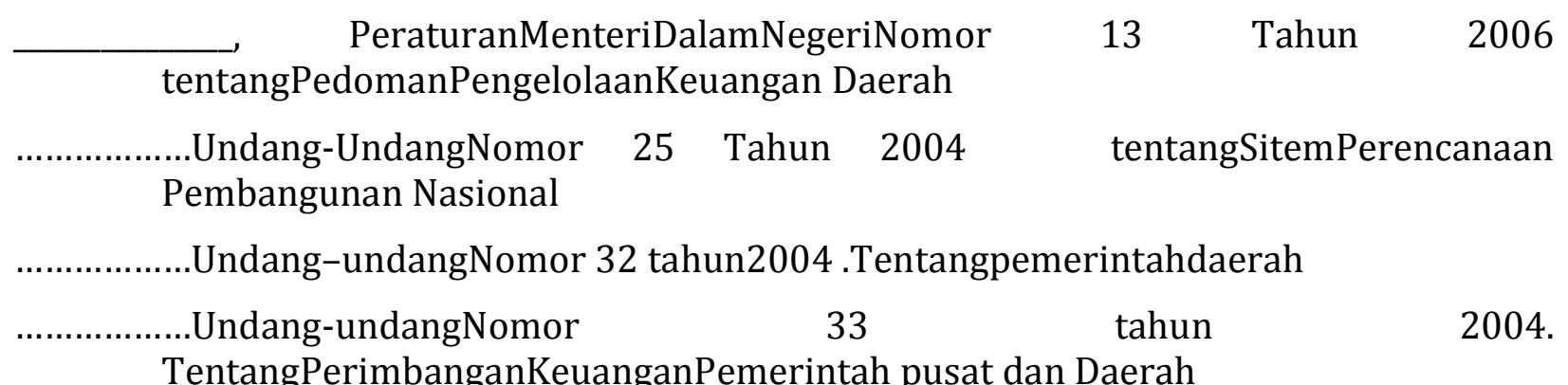

Zakarian, Syawal, 2012.

DampakDesentralisasiFiskalTerhadapPertumbuhanEKonomidanKetimpangan regional di KawasanTimur Indonesia. PublikasillmiahDesertasi PDIE FEB UB.

Zhang, Tao and Heng-fu Zou. 1997. Fiscal Decentralization, the Composition of Public Spending, and Regional Growth in India. Development Research Group Working Paper. Washington, D.C.: World Bank

Zhang, T. dan Zou, H., 1998. Fiscal Decentralization, Public Spending, and Economic Growth in China, Journal of Public Economics. LXVII:221-240

Zhang, T., and H. Zou. 2001. The growth impact of intersectoral and intergovernmental allocation of public expenditure: With applications to China and India. China Economic Review 2(1), 58-81. 